\title{
Delineation of Shallow Aquifers of Umuahia and Environs, Imo River Basin, Nigeria, Using Geo-Sounding Data
}

\author{
Uchenna Ugada', Alexander I. Opara' ${ }^{1}$, Theophilus T. Emberga ${ }^{2}$, Frank D. Ibim ${ }^{3}$, \\ Alexander I. Omenikoro ${ }^{2}$, Edwin N. Womuru ${ }^{3}$ \\ ${ }^{1}$ Department of Geosciences, School of Sciences, Federal University of Technology, Owerri, Nigeria \\ ${ }^{2}$ Department of Physics, Federal Polytechnic Nekede, Owerri, Nigeria \\ ${ }^{3}$ Department of Physics, Ignatius Ajuru University of Education, Port Harcourt, Nigeria \\ Email: oparazanda2001@yahoo.com
}

Received May 16, 2013; revised June 19, 2013; accepted July 15, 2013

Copyright (c) 2013 Uchenna Ugada et al. This is an open access article distributed under the Creative Commons Attribution License, which permits unrestricted use, distribution, and reproduction in any medium, provided the original work is properly cited.

\begin{abstract}
This work was undertaken to study the hydrogeophysical characteristics of Umuahia and environs, Imo River Basin using geophysical data. Thirty (30) vertical electrical sounding data with a maximum electrode spacing of (AB/2) of 500 meters were acquired using the Schlumberger electrode configuration. The VES data were interpreted using the conventional partial curve matching technique to obtain initial model parameters, which were used as input for computer iterative modelling using the OFFIX software. The study revealed three (3) to six (6) geo-electric layers with underlying shale beds. Aquifer apparent resistivity in the study area ranges from about 50 to $850 \Omega \mathrm{m}$ with the aquifer depth varying between $0.53-82.67 \mathrm{~m}$. Similarly, the aquifer thickness in the study area ranges from $0.8-110 \mathrm{~m}$, with very low thicknesses around Ajata Ibeku. These shallow aquifers with very small thicknesses in the western areas around Ajata Ibeku are believed to be perched or fractured shale units with very low or no yield. Finally, transverse resistances in the study area range from $200-3400 \Omega \mathrm{m}^{2}$ with low values in the western part. Information extracted from iso-resistivity models, geoelectric cross sections, litho logs and electric logs revealed a sandy clay lithology at very shallow depths with a thick layer of shale/clay extending to over $300 \mathrm{~m}$ within the western part. These shallow aquiferous units are however perched, partially saturated and may not have sufficient yield. Finally, this study has helped to delineate the aquifers of the study into two distinct zones, thus revealing a groundwater divide.
\end{abstract}

Keywords: Geo-Sounding; Aquifer Units; Resistivity; Transverse Resistance; Longitudinal Conductance; Nigeria

\section{Introduction}

The Umuahia area is underlain by the sedimentary rocks of the southeastern Nigeria. The study area constitutes the middle segment of the extensive Imo River Basin [1]. Two principal geologic formations delineated in the study area are the Benin Formation at the southwestern and central parts of the area, and the Ameki Formation which underlines the northeastern part. The inhabitants are mostly subsistence farmers who rely on perennial streams for their domestic water needs. In order to have portable water, many communities, private individuals, and age grades have at different times embarked on borehole projects. The indiscriminate search for groundwater has lead to the existence of failed boreholes and dry wells which pose great concern to the inhabitants of Umuahia and adjoining towns. A lot of these projects were incorrectly sited; some function seasonally, while others have been abandoned. These failures are mainly due to the inability to carry out detailed geophysical surveys that could delineate aquifers and groundwater potentials of Umuahia in addition to the poor knowledge of the geology underlying part of the study area. High productivity of many boreholes that already drilled in the area supports the prolific nature of the Benin Formation which appears at the southeastern part of the study area within Amachara, Ossa, Nkata, Umu-Ekwule, Olokoro and Umudike. This covers about a third quarter of the entire study area while the northwestern part which lies within the Ameki Formation where most of the Ibeku towns are located is associated with acute groundwater problems as a result of thick sequence of shale formation.

Geophysical methods for determining groundwater aquifer are based on the fact that certain physical proper- 
ties of the rock change considerably depending on their water contents thereby creating a physical boundary between the host rock and the water bearing strata. Such changes in physical properties interpreted by the presence of water include changes in elastic wave velocity, changes in density and increase or decrease in elastic conductivity. It has been established that groundwater is found in pore spaces of sediments such as sand, silt and clays (fractured). These rock bodies and sediments have their specific range of resistivity. The electrical resistivity of a given medium is dependent on such factors such as grain size, water content and porosity, of which porosity is the major control of the resistivity of rocks. Resistivity generally increases as porosity decreases and vice versa. Several authors have therefore delineated shallow aquifers and estimated aquifer hydraulic parameters using surface geophysical methods in different parts of the world [2-14].

This study is a detailed hydrogeophysical study of the area aimed at delineating the shallow aquiferous units in the study area. Geophysical sounding data were compared with lithological logs from boreholes and available electric logs for correlation purposes. In light of the foregoing, it is hoped that results from the present study would address the groundwater problems of part of the study area especially around Ibeku area, as well as help to reduce the cases of borehole failures within Umuahia and adjoining towns.

\subsection{Location, Geomorphology and Drainage of the Study Area}

The study area consists of parts of the present Umuahia North, Umuahia South and Ikwuano Local Government Areas of Abia state, Southeastern Nigeria. The area is accessible through the main roads that lead to Bende, Ikot Ekpene, Uzuakoli, Okigwe, Enugu and Aba. It lies between longitudes $7^{\circ} 23^{\prime}$ to $736^{\prime}$, and latitudes $5^{\circ} 26^{\prime}$ to $5^{\circ} 37^{\prime}$ This is shown in the topographic and location maps of the study area below (Figures 1(a)-(c)).

The study area which is characterized by a lot of features has a submerged or flooded bed in the wet season, a situation that always last till the middle of the rainy season [15]. The size of the local watershed in this area is different from those found in other areas; the extension of the hydrological system depends on what section of Umuahia and Ikwuano areas that is being discussed.

Onwuchuriba [15], revealed that the drainage pattern of this watershed influences the drainage density of the study area (defined as the ratio of length of all streams $(\mathrm{km})$ to the area of the watershed $\left(\mathrm{km}^{2}\right)$. In areas with dendritic and tree-like branching patterns, the valley that is associated with the study area extends in all directions while in areas with trellis drainage pattern, the valleys are oriented in lines [15].

\subsection{Geology of the Study Area}

The geology of the study area is that of the Imo River Basin [1], as shown in Figure 2. A striking feature in the geologic map is the similarity in the trend pattern of the Formations. Almost all the formations occur along NWSE bands that are grossly parallel to the regional strike. The rock units also get younger south westward, a direction that is parallel to the regional dip of the rock units $[1,16]$. There are two principal geological formations in the area namely: the Ameki Formation which appears at the western section and the Benin Formation which appears in the eastern part and covers a large part of the study area. The Ameki Formation of the Eocene to Oligocene age consists of medium to coarse grained white sandstones, bluish calcareous silt with mottled clays and thin limestone. Considerable lateral variation in lithology has been observed in many areas. The lower part of the formation consists of fine to coarse grained lenses of sandstones with abundant calcareous shales and thin shaly limestone. Lithologic units of the Ameki Formation fall into two general groups [17-19]; an upper grey-green sandstones/sandy clay and a lower unit with fine to coarse grained sandstones and intercalations of calcareous shales and thin shaly limestone.

The Benin Formation overlies the Ameki Formation and dips south westward. The Ogwashi/Asaba Formation on the other hand is overlain by the Benin Formation which is the youngest formation (Miocene to Recent) in the Imo River Basin. It occupies the middle and lower regions and directly overlies more than half of the Basin. The Benin Formation is made up of very friable sands with minor intercalations of clays. It is mostly coarsegrained, pebbly, poorly sorted and contains pods and lenses of fine grained sands, sandy clays and clays [18, 20].

The Formation is in part cross-stratified and the foreset beds alternate between coarse and fine-grained sands. Petrographic study on several thin sections [21] revealed that quartz makes up more than $95 \%$ of all grains; but other scholars revealed the possible presence of more percentages to other skeletal materials including feldspar $[22,23]$. The Benin Formation and the other formations are covered (at their exposed areas) to varied depths by red acidic sandy soils and mangrove soils (lateritic soils). The formation sediments were deposited during the late Tertiary-Early Quatenary Period [24]. At Umudike, the formation is very shallow [25].

\section{Data Acquisition and Processing}

Most electrical techniques inject electrical current into the ground by direct coupling with the ground. The re- 


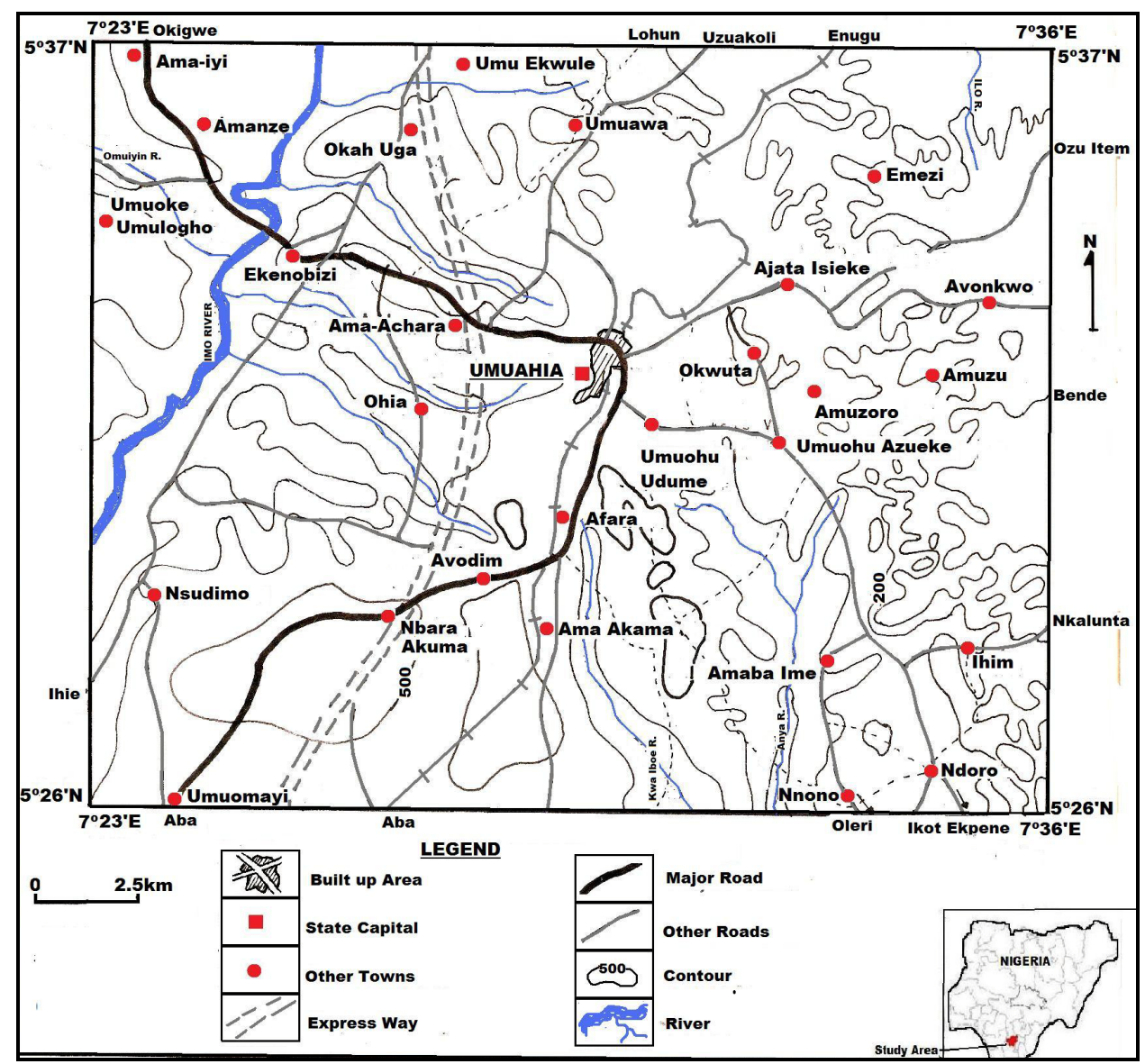

(a)

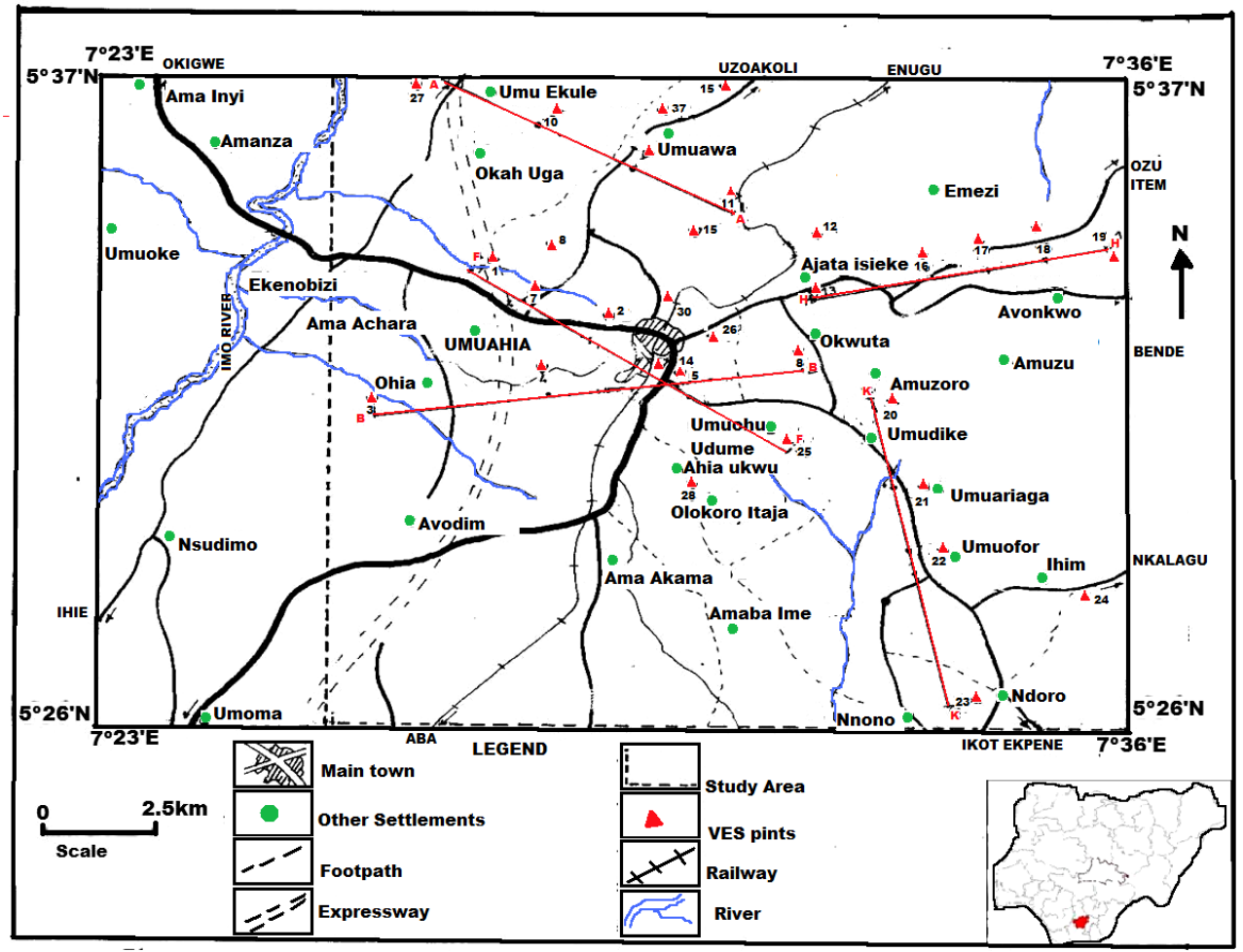

(b) 


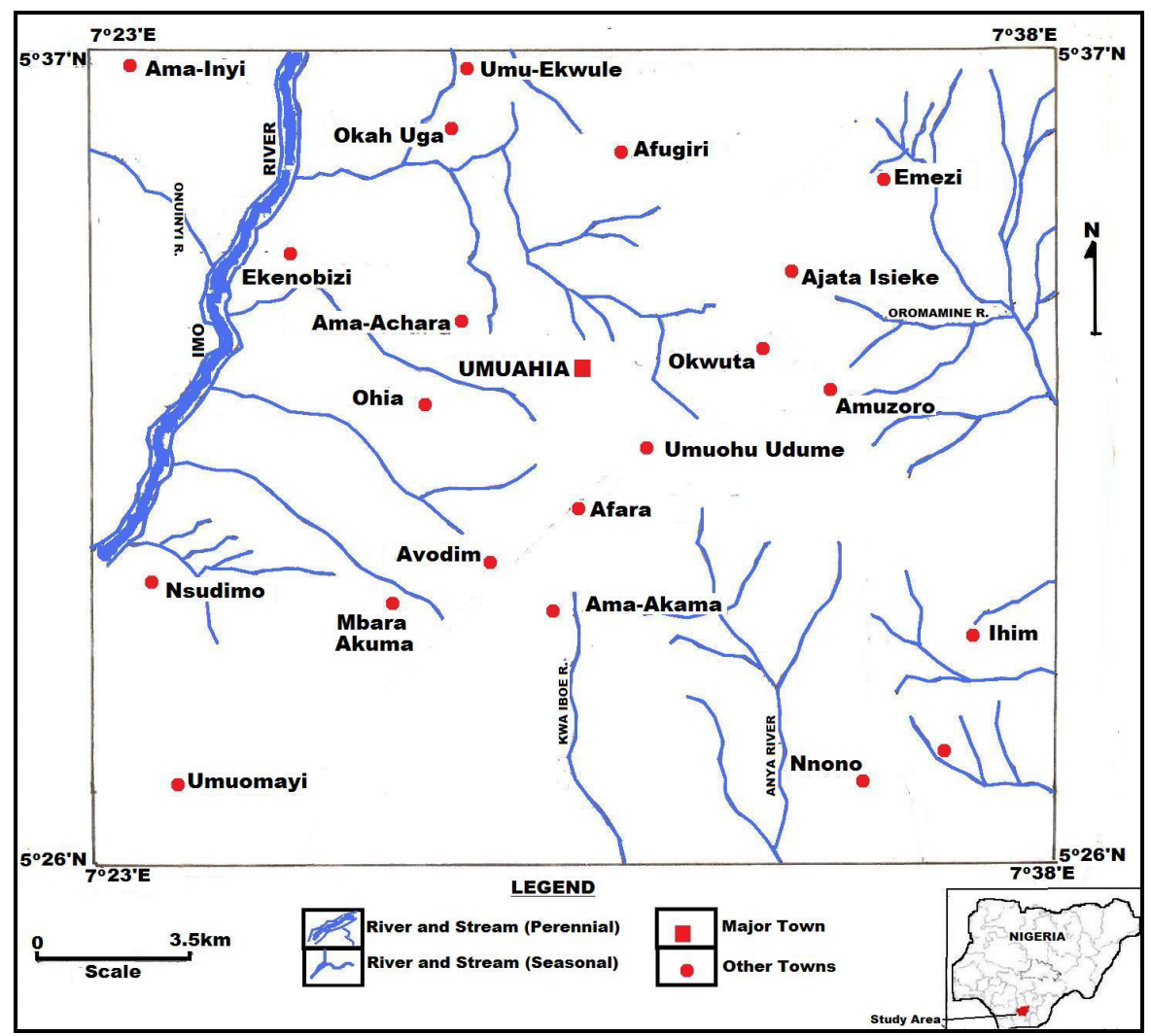

(c)

Figure 1. (a) Topography (elevation) map of the study area; (b) Location map of the study area showing VES sounding points and interpretative cross sections; (c) Drainage map of the study area.

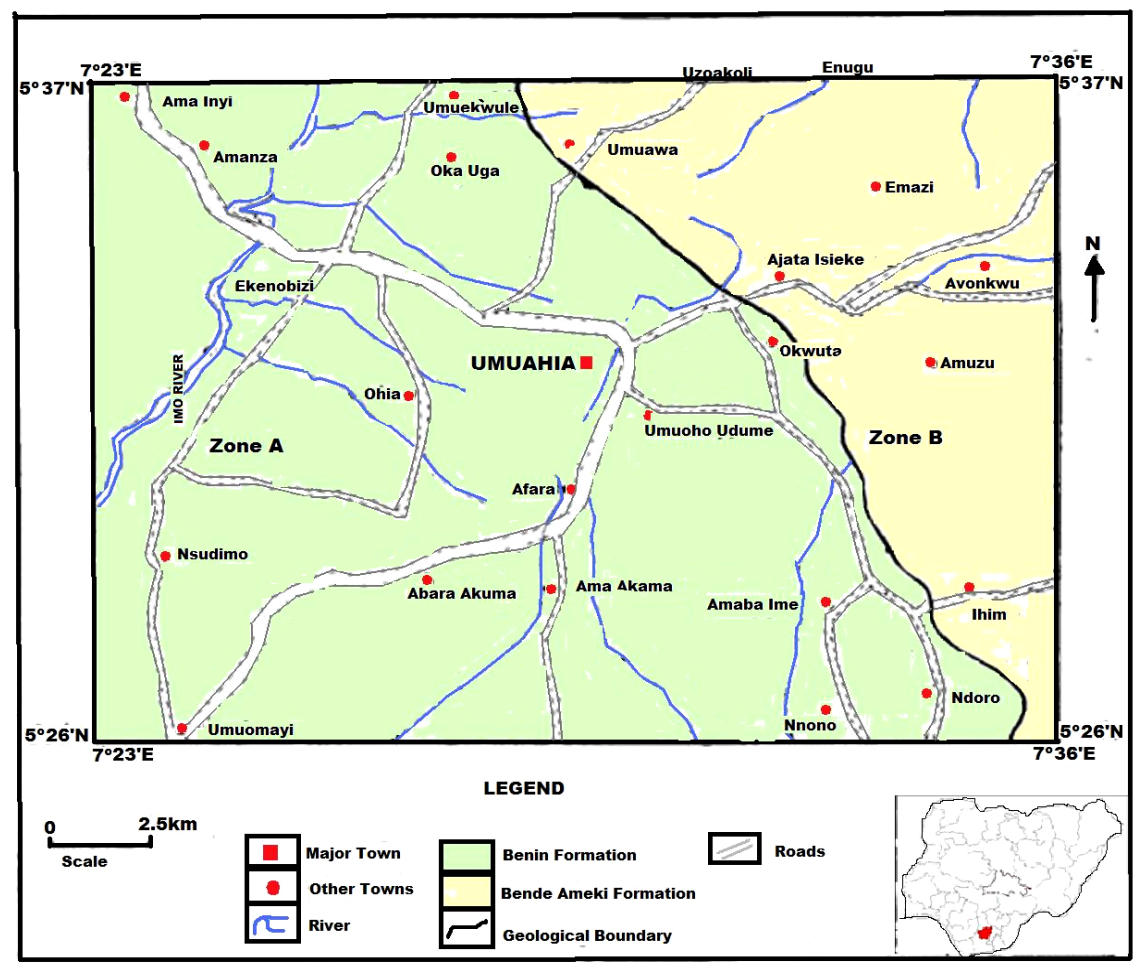

Figure 2. Geological Map of the study area showing the established geologic boundary. 
sulting electrical potential is then used to measure the variation in ground conductivity, or its inverse, resistivity. Since resistivity is a fundamental electrical property of rock materials closely related to their lithology, the determination of the subsurface distribution of resistivity from measurements on the surface yields useful information on the structure and composition of buried formations.

Vertical electrical sounding using Schlumberger array measures earth resistivity by passing an electrical current into the ground and measuring the resulting potentials created in the earth. This method involves the supply of direct current or low frequency alternating current into the ground through a pair of current electrodes and the measurement of the resulting potential through another pair of electrodes called potential electrodes. Since the current is known and the potential can be measured, an apparent resistivity can be calculated. They resistivity of the subsurface material observed is a function of the magnitude of the current, the recorded potential difference and the geometry of the electrode array used. In general, the depth of penetration is small in this method and only shallow subsurface layers can be surveyed [4, 8].

The geo-sounding data was collected using Vertical electrical sounding using the Schlumberger array. Four electrode array methods are generally used at the surface, one pair for introducing current into the earth, the other pair for measurement of the potentials associated with the current. Current and potential electrodes were made of non polarisable copper electrodes. The potential drop ratio method is a variation of this procedure used for determining resistivity. Similarly, all resistivity techniques in general use require the measurement of apparent resistivity $\rho a$, which is obtained from the four electrode array. The basic equation is given as:

$$
\rho a=2 \pi G\left(\frac{\Delta v}{I}\right)
$$

A total of thirty (30) resistivity soundings with some near existing boreholes were acquired for correlation purposes. The maximum spread used was $A B=1000 \mathrm{~m}$ and was carried out using the ABEM Terameter SAS 4000 which gave a direct readout of resistance (V/I). The intervals between the potentials and current electrodes were increased at appropriate steps in order to obtain potential differences large enough to be measured with satisfactory precision. The observed field data were converted to apparent resistivity values by multiplying with the Schlumberger geometric factor. The geometric factor for the Schlumberger array is given by:

$$
K=\pi\left(\frac{a^{2}}{b}-\frac{b}{4}\right)
$$

The data obtained was plotted as a graph of apparent resistivity against half current electrode spacing for the Schlumberger array. The electrode spacing at which inflection occurs on the graph provides an idea of the depth to the interface. A useful approximation is that the depth of the interface is equal to one third (1/3) of the electrode spacing at which the point of inflection occurs [26]. This approximation has found useful applications in computer iterative modeling. The sounding curve for each point was obtained by plotting the apparent resistivity on the ordinate against the half current electrode spacing, on a bi-logarithmic paper. Geo-electric layer parameters such as apparent resistivity and thickness obtained from both partial curve matching and the method of asymptotes were used as input data for computer iterative modeling $[27,28]$. Hence, the computer program allowed the reading obtained from the field to be converted to apparent resistivity values and to be stored on magnetic tapes for the detailed quantitative interpretation using the OFFIX software.

\section{Result Presentation and Interpretation}

Results of the curve matching were studied in details leading to qualitative and quantitative interpretations. Firstly, the shape of the curves for each sounding gave an insight into the character of the beds or layers between the surface and the maximum depth of penetration. This is because the shape of a VES curve depends on the number of layers in the subsurface, the thickness of each layer, and the ratio of the resistivity of the layers [29]. The curve types identified ranges from simple QQ to KQQ, KHK, AKQ, KQH, QHK, HKQ, to complex KHKQ, KQHK types, reflecting different facies or lithological variations in the area. The KHKQ type is the most preponderant constituting about $16.7 \%$. This is followed by the AKQ and KQQH types which constituted about $10 \%$. The other curve types include the KQQ, AKQQ, QHK, HKQ, HKQQ and KHAK curve types (Table 1). The general signature of the curves suggests alternate sequence of resistive-conductive layers. Figure 3 shows typical curve types from the study area.

\subsection{Aquifer Resistivity, Depth and Thickness}

Apparent resistivity across the study area has been determined from geoelectric soundings and presented as a contour map in Figure 4. The minimum aquifer apparent resistivity is about $109 \Omega \mathrm{m}$ near Itaja Olokoro while the maximum apparent resistivity is about $850 \Omega \mathrm{m}$ near Ajata Ibeku. The mean aquifer apparent resistivity in the study area is in the range of $253.2 \Omega \mathrm{m}$.

Depth to water table has been deduced from sounding results and the indications are that the water table is shallow in the Umuokwom Ohiya area with a depth of 18.66 


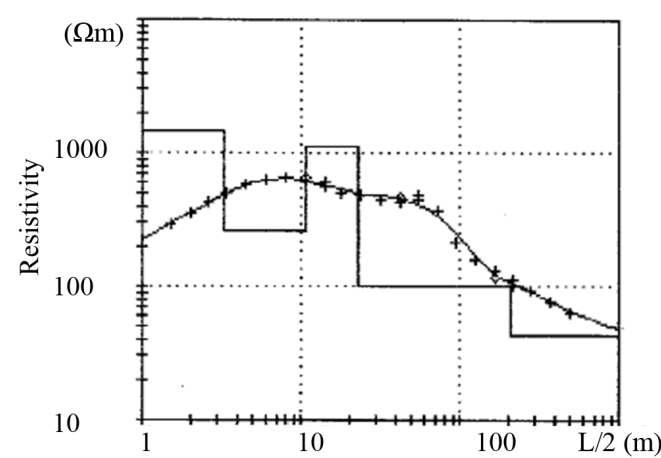

(a)

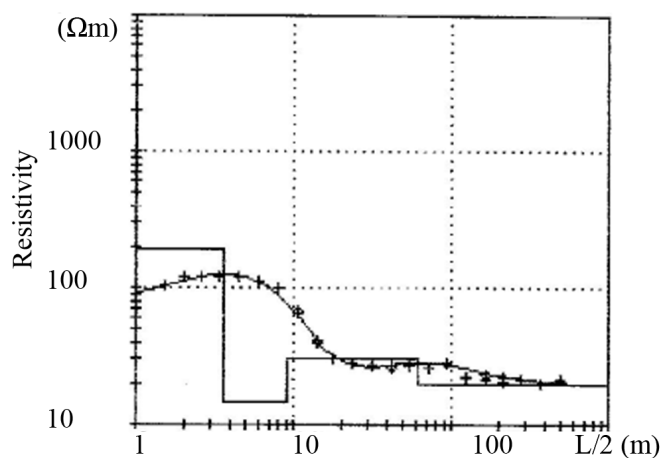

(b)

Figure 3. Typical curve types from the study area: (a) Umu- ofor Ikwuano (VES 22); (b) Umuire Ibeku Umuahia North LGA (VES 19).

Table 1. Interpreted layer parameters of the geophysical sounding of Umuahia and environs.

\begin{tabular}{|c|c|c|c|c|c|c|c|c|c|c|c|c|}
\hline \multirow{2}{*}{ VES No } & \multirow[b]{2}{*}{ Location } & \multirow[b]{2}{*}{ Longitude } & \multirow[b]{2}{*}{ Latitude } & \multirow{2}{*}{$\begin{array}{l}\text { No of } \\
\text { layers }\end{array}$} & \multicolumn{6}{|c|}{ Layer resistivity ( $\Omega \mathrm{m})$} & \multirow{2}{*}{$\begin{array}{l}\text { Curve } \\
\text { Type }\end{array}$} & \multirow{2}{*}{$\begin{array}{r}\text { Depth to } \\
\text { water (m) }\end{array}$} \\
\hline & & & & & $\rho_{1}$ & $\rho_{2}$ & $\rho_{3}$ & $\rho_{4}$ & $\rho_{5}$ & $\rho_{6}$ & & \\
\hline 1 & Amachara & 7.452 & 5.545 & 7 & 47.3 & 2610 & 507 & 900 & 345 & 108 & KHKQ & 47.3 \\
\hline 2 & Umuchoko Nkata & 7.511 & 5.537 & 7 & 1010 & 1470 & 176 & 212 & 175 & 83 & KHKQ & 60.53 \\
\hline 3 & Umuokwom Ohiya & 7.456 & 5.526 & 7 & 124 & 1010 & 302 & 1400 & 323 & 102 & KHKQ & 18.8 \\
\hline 4 & Planning Commission & 7.49 & 5.526 & 6 & 480 & 1020 & 727 & 194 & 62 & & KQQ & 54.73 \\
\hline 5 & Federal High Court & 7.511 & 5.527 & 6 & 1010 & 1500 & 784 & 206 & 85 & & KHK & 57.67 \\
\hline 6 & Umuhute Azueke Ibeku & 7.54 & 5.519 & 7 & 202 & 519 & 477 & 27.7 & 155 & 39.6 & KQHK & 45.53 \\
\hline 7 & Atta Ibeku & 7.482 & 5.554 & 7 & 113 & 1440 & 3210 & 800 & 448 & 25.6 & AKQQ & 43.47 \\
\hline 8 & Ezeleke Umuekwule & 7.439 & 5.552 & 7 & 790 & 1600 & 88 & 122 & 207 & 26.6 & KHAK & 60.33 \\
\hline 9 & Umuawa Alaocha & 7.459 & 5.564 & 7 & 566 & 212 & 900 & 774 & 459 & 164 & HKQQ & 51.73 \\
\hline 11 & Umuawa Alaocha & 7.462 & 5.563 & 7 & 577 & 190 & 682 & 752 & 109 & 70 & HAKQ & 14.07 \\
\hline 12 & Ukome Ibeku & 7.529 & 5.557 & 7 & 186 & 980 & 163 & 21.5 & 14.4 & 19.9 & $\mathrm{KQQH}$ & 1.4 \\
\hline 13 & Isieke Ibeku & 7.55 & 5.557 & 5 & 2130 & 254 & 26.3 & 6.2 & & & QQ & 4.47 \\
\hline 14 & M. Dei Umuahia & 7.528 & 5.477 & 6 & 122 & 457 & 1970 & 457 & 178 & & $\mathrm{AKQ}$ & 82.67 \\
\hline 15 & Ubani Ibeku & 7.505 & 5.568 & 6 & 141 & 202 & 20 & 13 & 13.3 & & $\mathrm{KQH}$ & 0.7 \\
\hline 16 & Ajata Ibeku & 7.554 & 5.542 & 7 & 509 & 850 & 8.9 & 28.6 & 13.1 & 23.5 & KHKH & 1.2 \\
\hline 17 & Ajata Ibeku & 7.539 & 5.541 & 7 & 644 & 9.3 & 29.6 & 14.2 & 21.7 & 22.7 & HKHA & 0.67 \\
\hline 18 & Ajata Ibeku & 7.567 & 5.54 & 7 & 408 & 1660 & 193 & 20.8 & 17.2 & 24.7 & KQQH & 0.8 \\
\hline 19 & Umuire Ibeku & 7.593 & 5.548 & 6 & 830 & 191 & 14.5 & 30.6 & 19.9 & & QHK & 0.53 \\
\hline 20 & Govt College Umuahia & 7.538 & 5.499 & 6 & 3510 & 910 & 2720 & 390 & 50 & & HKQ & 67.27 \\
\hline 23 & Nnono Oboro & 7.547 & 5.434 & 6 & 250 & 747 & 2190 & 194 & 60 & & AKQ & 80 \\
\hline 24 & Umulu Ibere & 7.585 & 5.436 & 6 & 726 & 118 & 84 & 136 & 60.1 & & QHK & 42.76 \\
\hline 25 & Isicourt Olokoro & 7.539 & 5.459 & 7 & 1050 & 2430 & 890 & 570 & 283 & 60.1 & KQQQ & 34.37 \\
\hline 26 & Ministry of Agric Umuahia & 7.537 & 5.526 & 7 & 170 & 1040 & 294 & 458 & 1710 & 111 & KHAK & 80.67 \\
\hline 27 & Okai-Uga Nkwoegu & 7.454 & 5.557 & 7 & 186 & 2410 & 1650 & 900 & 412 & 141 & KQQH & 76.67 \\
\hline 28 & Itaja Olokoro & 7.525 & 5.451 & 7 & 118 & 1500 & 484 & 3980 & 1220 & 84 & KHKQ & 40.73 \\
\hline 30 & Low Cost Umuahia & 7.52 & 5.526 & 7 & 186 & 1640 & 3430 & 1910 & 870 & 184 & AKQQ & 70 \\
\hline 31 & Okaiuga Nkwoegwu & 7.467 & 5.557 & 7 & 97 & 255 & 67 & 3800 & 417 & 27 & KHKQ & 65.4 \\
\hline
\end{tabular}


$m$ and much deeper in the Umuohu, Nnono Oboro area with a depth of over $80 \mathrm{~m}$ as shown in Figure 5. Mater Dei Cathederal has a depth of $82.67 \mathrm{~m}$ which is exceptionally deep compared to the sounding points around it. For the eastern part of the study area within Ibeku, depth to water table tends to appear at very shallow depths ranging from $0.53 \mathrm{~m}$ at Umuire Ibeku to $4.47 \mathrm{~m}$ at Okwoyi Isieke Ibeku.

Similarly, the Isopach map (Figure 6) revealed that the aquifers of the study area are highly variable in thickness with the thinnest in the vicinity of VES 31 . The thicknesses range from $25.2 \mathrm{~m}$ to $126.2 \mathrm{~m}$ within zone A, while zone $\mathrm{B}$ appears at a very shallow depth ranging from $0.8 \mathrm{~m}$ near Umuire Ibeku to $6.7 \mathrm{~m}$ near Okwoyi Ishieke Ibeku. From Figure 6, the Blue (0 to 5) and Black ( -5 to 0$)$ colours correspond to most Ibeku towns.

Figure 7 shows the variation of aquifer tranverse resistance $T_{r}$ across the study area. The $T_{r}$ values are highest towards the seastern and central parts underlain by Benin Formation. The transverse unit resistance $\left(T_{r}\right)$ map is considered a unique map for hydrological classifica-

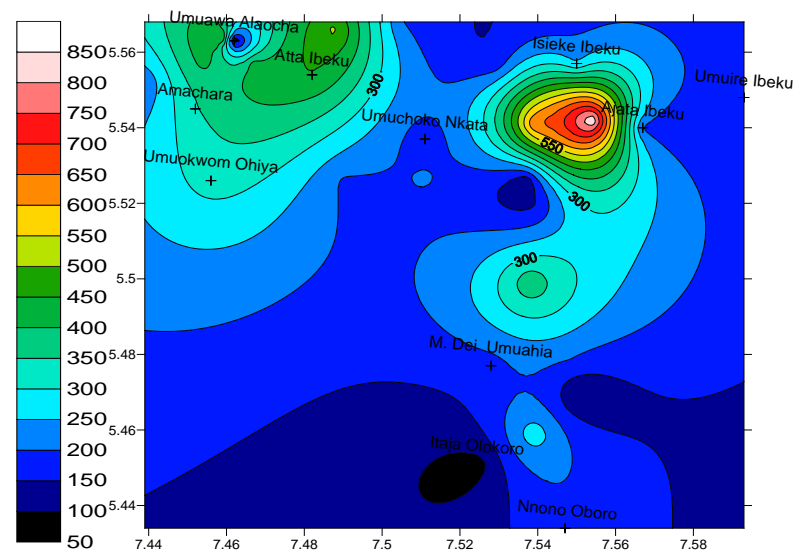

Figure 4. Plot of Aquifer apparent resistivity of Umuahia and adjoining areas.

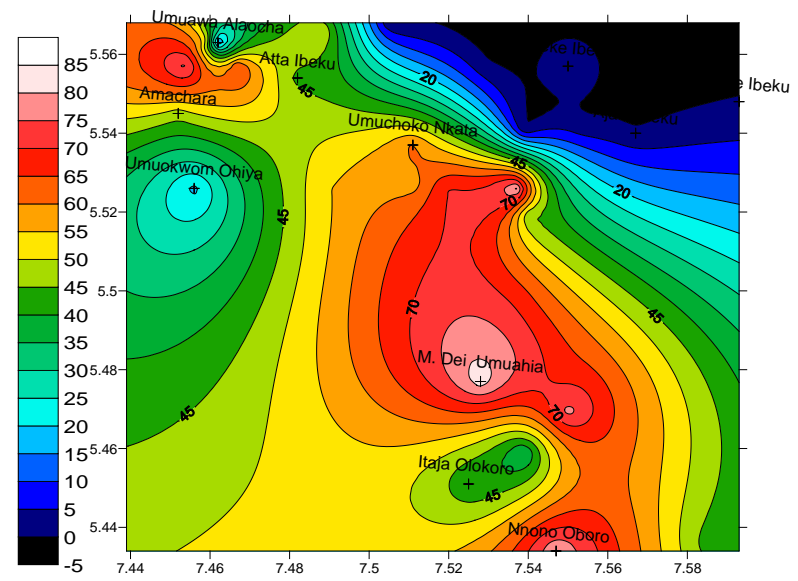

Figure 5. Depth to water table in Umuahia and adjoining areas in metres.

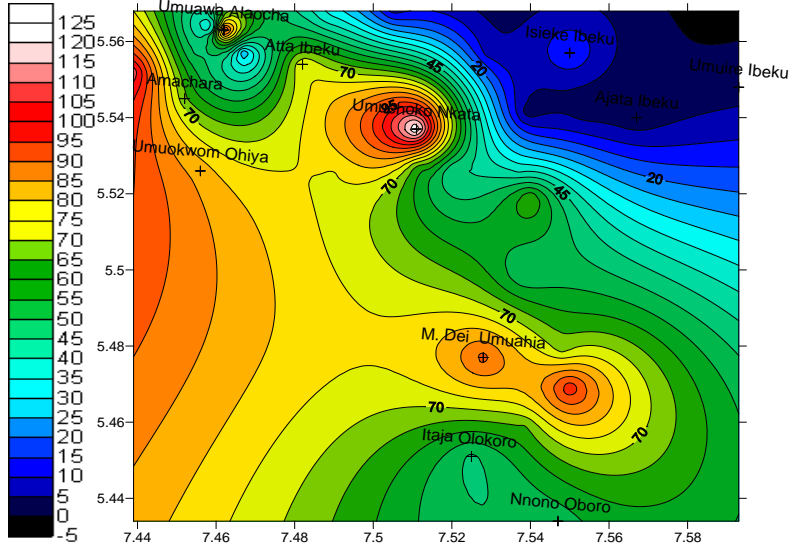

Figure 6. Contour map (Isopach) of the aquifer thickness in the study area.

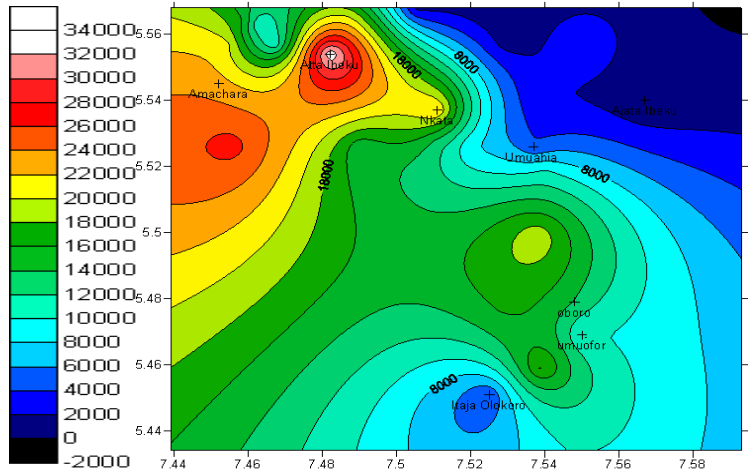

Figure 7. Plot of transverse resistance $\left(\mathrm{Ohm} \cdot \mathrm{m}^{2}\right)$ of Umuahia and adjoining areas.

tion of an environment with a thick sedimentary sequence, as is in the case under study. This is because the transverse unit resistance $\left(T_{r}\right)$ which is a product of aquifer thickness (h) and resistivity ( $\rho$ ), is closely related to transmissivity ( $\mathrm{T}$ ) which is a product of aquifer thickness and hydraulic conductivity (K). Thus the eastern and central parts of the study area (Figure 7) where the total transverse unit resistance values are high, are expected to correlate with areas having the highest hydraulic transmissivity ( $\mathrm{T}$ ) and storage coefficients whereas the western parts of the study area with low values of total transverse unit resistance $\left(T_{r}\right)$ are expected to have the least transmissivity $(\mathrm{T})$ and permeability values. Transverse resistance across the study area was estimated by taking the product of aquifer apparent resistivity and aquifer thickness (m). In line with the geology of the study area (Figure 2), the northwestern part has the least transverse resistance of about $4107 \Omega \mathrm{m}^{2}$ near Itaja within the light blue coloured area (4000 - 6000) while the maximum transverse resistance is about $33,580 \Omega \mathrm{m}^{2}$ near Atta Ibeku with the red and pink colours $(30,000-34,000)$. This has a mean value of $15408.39 \Omega \mathrm{m}^{2}$. For the eastern part within Ibeku, the aquifer transverse resistance is 231 $\Omega \mathrm{m}^{2}$ near Ajata Ibeku corresponding to the region with 
dark blue colour (0 - 2000). The dark blue area $(0$ - 2000) up to the black coloured region $(-2000-0)$ may not be productive since the transverse resistance value is low.

Similarly, a contour map of the aquifer longitudinal conductance $S$ is shown in Figure 8. The figure revealed that around Ibeku and within the western part of the study area which lie within the Ameki Formation, the aquifer $S$ values are low ( $-0.05-0.2$ mhos) whereas the $\mathrm{S}$ values are high in the central and eastern part (0.8 1.00 mhos) which are underlain by the Benin Formation. The central and eastern part of the study area and other zones of high $\mathrm{S}$ values are probably underlain by thick layers of conducting sediments. These could either be fully saturated zones or areas with high percentage of conducting clays or both. Although the aquifer thickness is more in the central and eastern half of the study area, underlain by the Benin Formation, the relatively low resistivity of the aquiferous zones could account for the higher values of $S$ in these areas. The longitudinal conductance map may also characterize the relief of the supporting horizon.

\subsection{Interpretative Geo-Electric Crzoss Sections}

Interpretations from electrical resistivity soundings carried out around the study area were used to generate geo-electric cross sections. Similarly, five profiles which include $\mathrm{A}-\mathrm{A}^{1}, \mathrm{~B}-\mathrm{B}^{1}, \mathrm{~F}-\mathrm{F}^{1}, \mathrm{H}-\mathrm{H}^{1}$ and $\mathrm{K}-\mathrm{K}^{1}$ were taken as shown in Figure 1(a) for the purpose of interpretation. Six distinct geo-electric layers representative of the subsurface lithology in the study area were noted with conductive (clay) layer at the base having resistivity less than $160 \Omega \mathrm{m}$. Two of the cross sections covering the two distinct hydrogeologic zones are presented below and were used to infer the hydrostratigraphy of the study area.

Profile A- $\mathrm{A}^{1}$ is $8.2 \mathrm{~km}$ long and is oriented northwestsoutheast of the study area. It cuts across Umuewelike, Okai Ugah and Umuowa areas. The section revealed six

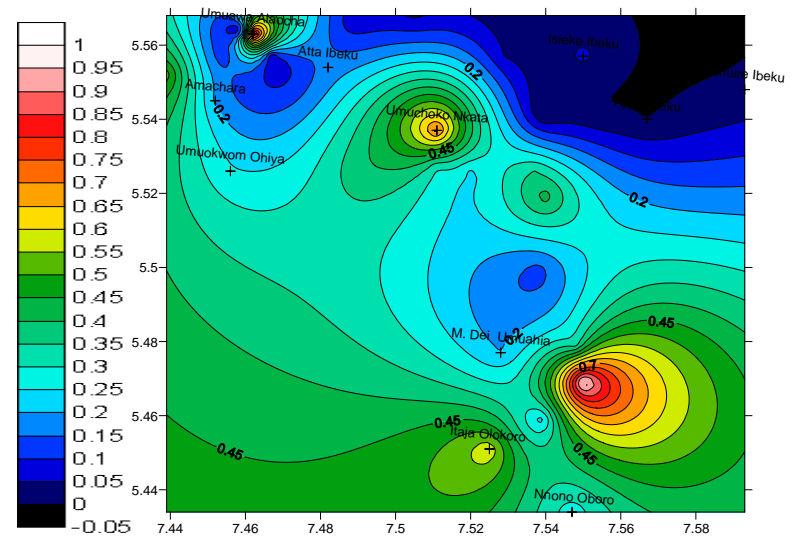

Figure 8. Plot of Longitudinal Conductance (mhos.m) of Umuahia and adjoining areas. litho-units with the conductive (clay) layer at the base having resistivity values less than $160 \Omega \mathrm{m}$; this is overlain by the clayey sand unit with resistivity ranging from $100 \Omega \mathrm{m}$ to $500 \Omega \mathrm{m}$. Overlying this layer is the saturated sand unit with resistivity ranging from $578 \Omega \mathrm{m}$ to 3800 $\Omega \mathrm{m}$. This layer is overlain by silty sand with resistivity ranging from $200 \Omega \mathrm{m}$ to $1650 \Omega \mathrm{m}$, the clayey-sand having the resistivity range of $160 \Omega \mathrm{m}$ to $2410 \Omega \mathrm{m}$ and the top soil with a resistivity of $186 \Omega \mathrm{m}$ to $515 \Omega \mathrm{m}$, in that order (Figure 9(a)).

Profile $F-\mathrm{F}^{1}$ is $10 \mathrm{~km}$ long and trends in the northwest-southeast of the study area cutting across Amachara, Atta, Federal High Court out post and Umuobia-Isicourt. The section revealed the presence of six litho units with the conductive (clay) layer at the base having resistivity values ranging from $25 \Omega \mathrm{m}$ to $108 \Omega \mathrm{m}$; this is overlain by the saturated sand unit with resistivity ranging from $158 \Omega \mathrm{m}$ to $636 \Omega \mathrm{m}$; overlying this is the sandy unit having resistivity ranging from $206 \Omega \mathrm{m}$ to $900 \Omega \mathrm{m}$; the sandy unit is overlain by silty sand litho unit with resistivity ranging from $184 \Omega \mathrm{m}$ to $3210 \Omega \mathrm{m}$; this is overlain by the unit modeled as laterite having resistivity ranging from $870 \Omega \mathrm{m}$ to $2610 \Omega \mathrm{m}$, the thickness of this unit reduces and finally disappears towards Federal High Court out post; overlying this, is the topmost layer modeled as top soil with resistivity ranging from $47 \Omega \mathrm{m}$ to $1050 \Omega \mathrm{m}$ (Figure 9(b)).

\section{Well to Vertical Electrical Sounding Correlations}

Two of the VES points from the study area with existing electric and lithology data are presented below for correlation purposes.

From the lithological log of area, the saturated zone appears between $310 \mathrm{ft}$ and $380 \mathrm{ft}$ while the geoelectric section of VES 7 revealed that the saturated zone appears between 142.61ft and 258.09ft. From the Electric log of Amangwu Olokoro, resistivity values ranges from 799 $\Omega \mathrm{m}$ at the depth range of $70 \mathrm{ft}$ to $150 \mathrm{ft}$, to $869 \Omega \mathrm{m}$ between $320 \mathrm{ft}$ and $380 \mathrm{ft}$. For the saturated zone, the electric log of Amangwu Olokoro revealed a resistivity value of $869 \Omega \mathrm{m}$, while that of the geo-electric section is given as $447.8 \Omega \mathrm{m}$. A fairly good correlation therefore is established between the electric log, litho-log and geo-electric section of Amangwu Olokoro as shown in Figure 10(a) below.

Similarly, from the lithological log of Umuihie-Odo, the saturated zone appears between $200 \mathrm{ft}$ and $410 \mathrm{ft}$ while for the geoelectric section of VES 6 the saturated zone appears between $148.73 \mathrm{ft}$ and $290.9 \mathrm{ft}$. From the Electric $\log$ of Umuihie-Odo, resistivity value ranges from 130 $\Omega \mathrm{m}$ at the depth of $98 \mathrm{ft}$ and $107 \mathrm{ft}$ to $100 \Omega \mathrm{m}$ between $290 \mathrm{ft}$ and $390 \mathrm{ft}$. For the saturated zone, Umuihie-Odo electric log reveals resistivity value of between $290 \mathrm{ft}$ and $390 \mathrm{ft}$ to be $100 \Omega \mathrm{m}$ while that of the geoelectric section 


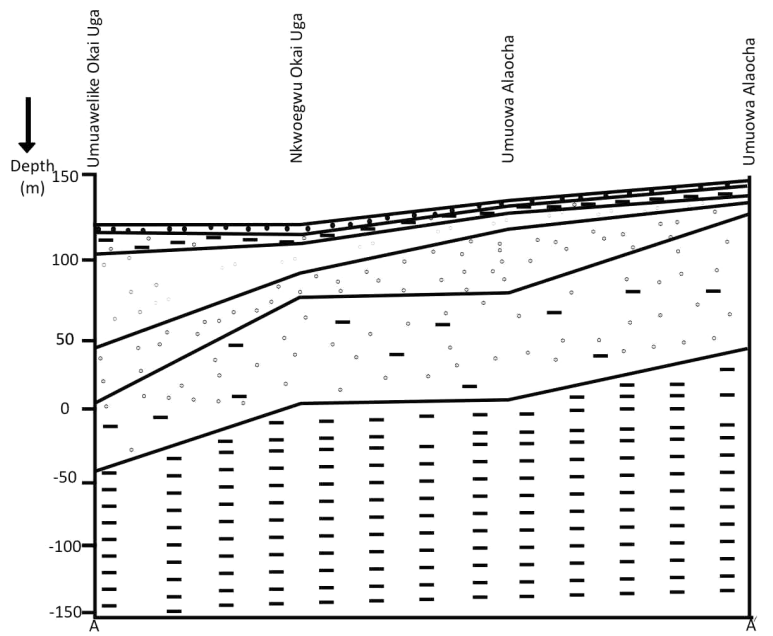

(a)
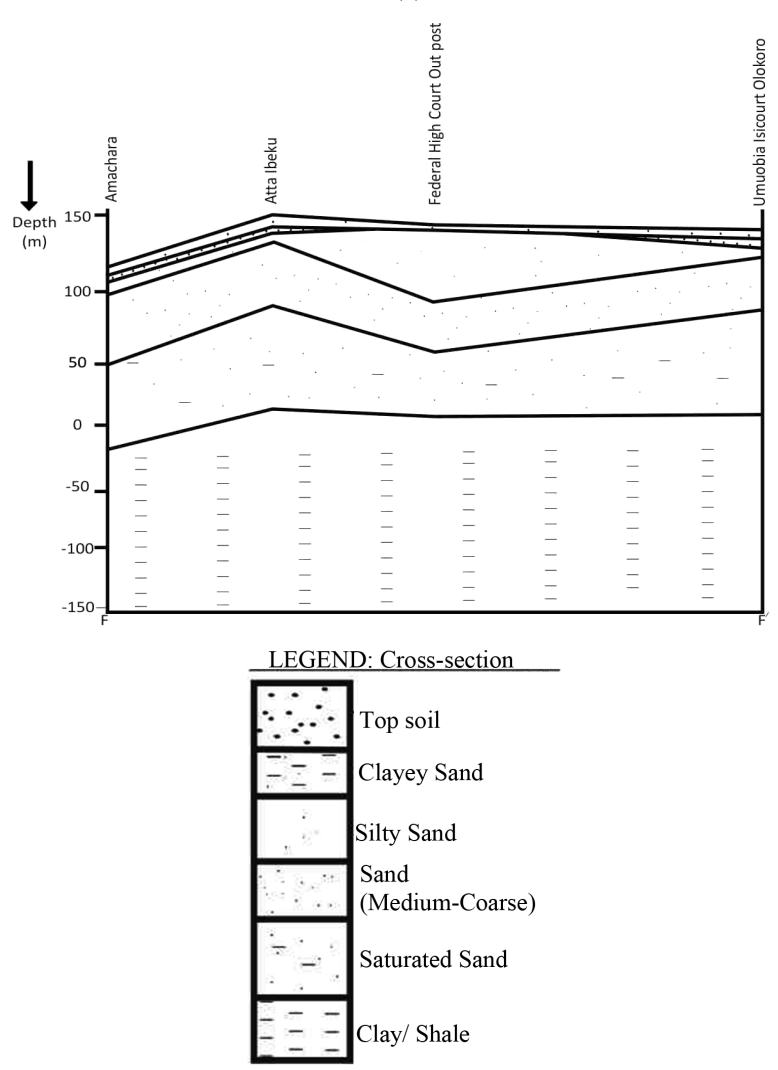

(b)

Figure 9. (a) Interpretative cross section showing A-A $A^{1}$ Profile; (b) Interpretative cross section showing F-F ${ }^{1}$ Profile.

of VES 6 is $155 \Omega \mathrm{m}$. Figure 10(b) therefore shows a fair correlation between the electric log, litho-log and geoelectric section of VES 6.

Similarly, from the lithological log of Umuihie-Odo, the saturated zone appears between $200 \mathrm{ft}$ and $410 \mathrm{ft}$ while for the geoelectric section of VES 6 the saturated zone appears between 148.73ft and 290.9ft. From the Electric log of Umuihie-Odo, resistivity value ranges from 130
$\Omega \mathrm{m}$ at the depth of $98 \mathrm{ft}$ and $107 \mathrm{ft}$ to $100 \Omega \mathrm{m}$ between $290 \mathrm{ft}$ and $390 \mathrm{ft}$. For the saturated zone, Umuihie-Odo electric log reveals resistivity value of between $290 \mathrm{ft}$ and $390 \mathrm{ft}$ to be $100 \Omega \mathrm{m}$ while that of the geoelectric section of VES 6 is $155 \Omega \mathrm{m}$. Figure 10(b) therefore shows a fair correlation between the electric log, litho-log and geoelectric section of VES 6.

\subsection{Iso-Resistivity Model across the Study Area}

Based on the assumption that the effective depth of transmission of electric current in the ground is two third

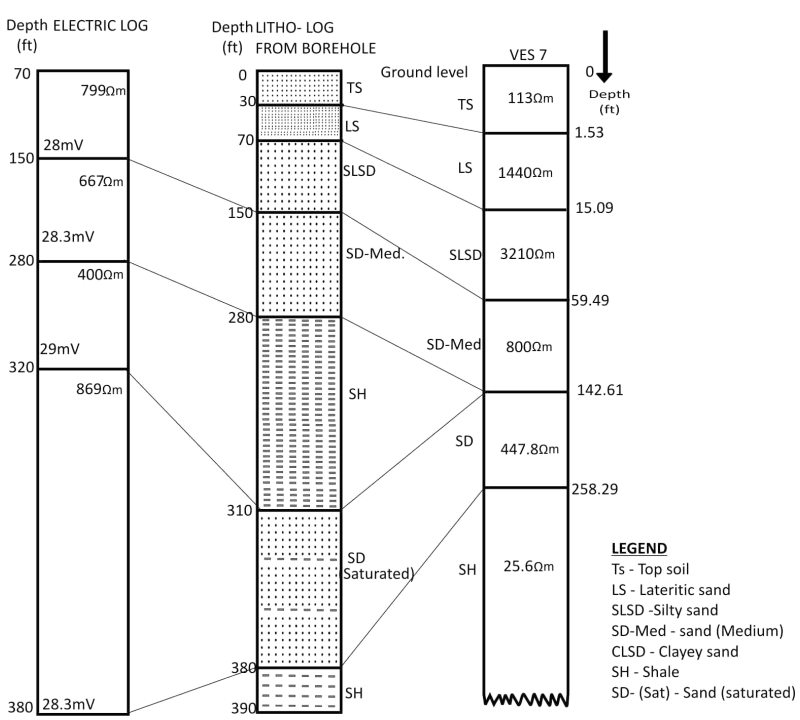

(a)

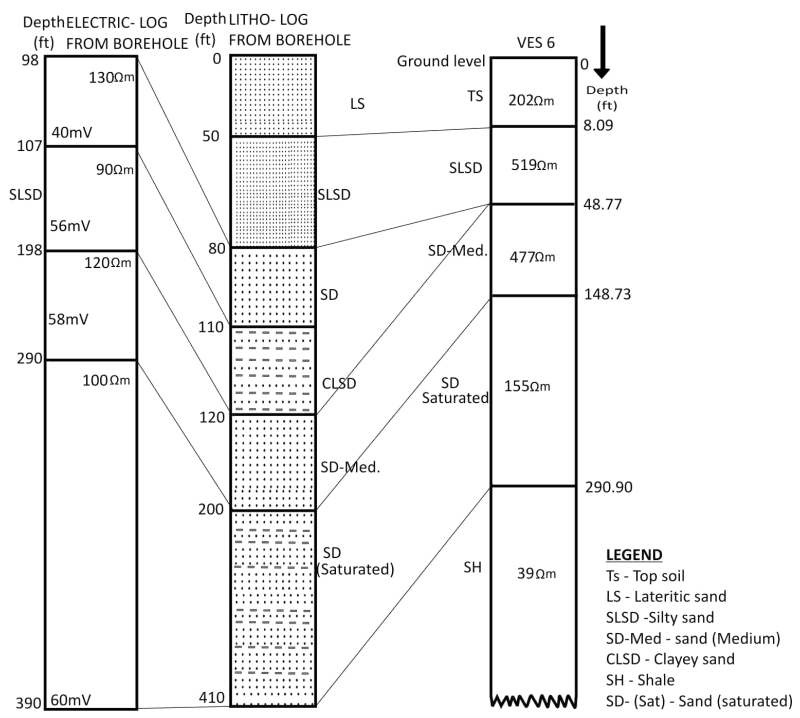

(b)

Figure 10. (a) Correlation of the results of VES 7 with the Electric log and the litho-log from borehole at Amangwu Olokoro; (b) Correlation of the results of VES 6 with the Electric log and the litho-log from borehole at UmuihieOdo. 
Table 2. Iso-resistivity modeling (downward continuation) of resistivity across the study area.

\begin{tabular}{|c|c|c|c|c|c|c|c|c|c|c|c|}
\hline $\begin{array}{l}\text { VES } \\
\text { NO }\end{array}$ & $\begin{array}{c}\mathrm{AB} / 2 \\
(\mathrm{~m})=10\end{array}$ & $\begin{array}{c}\mathrm{AB} / 2 \\
(\mathrm{~m})=15\end{array}$ & $\begin{array}{c}A B / 2 \\
(m)=24\end{array}$ & $\begin{array}{c}A B / 2 \\
(m)=50\end{array}$ & $\begin{array}{c}\mathrm{AB} / 2 \\
(\mathrm{~m})=75\end{array}$ & $\begin{array}{c}\mathrm{AB} / 2 \\
(\mathrm{~m})=100\end{array}$ & $\begin{array}{c}A B / 2 \\
(m)=150\end{array}$ & $\begin{array}{c}A B / 2 \\
(m)=200\end{array}$ & $\begin{array}{c}A B / 2 \\
(m)=250\end{array}$ & $\begin{array}{c}A B / 2 \\
(m)=300\end{array}$ & $\begin{array}{c}A B / 2 \\
(m)=500\end{array}$ \\
\hline 1 & 555 & 575.9 & 673 & 710.9 & 638.8 & 524.2 & 387.5 & 311.9 & 226.2 & 173.3 & 130 \\
\hline 2 & 1242 & 1065 & 751 & 251.1 & 218.9 & 203.4 & 176 & 185.5 & 177.9 & 170.9 & 129.6 \\
\hline 3 & 526.9 & 526.2 & 563.9 & 713.9 & 641.6 & 518.4 & 393.6 & 301.9 & 218 & 170.9 & 123.4 \\
\hline 4 & 864.4 & 911.2 & 850.1 & 475.7 & 202.4 & 136.7 & 111.3 & 114.4 & 111.2 & 108.9 & 100 \\
\hline 5 & 1246 & 1065 & 751.4 & 250.2 & 218.1 & 203.4 & 171.6 & 185.5 & 186.7 & 171.2 & 130 \\
\hline 6 & 463 & 450.3 & 390 & 208.1 & 105.6 & 62.9 & 54.84 & 62.38 & 63.8 & 60.4 & 56.4 \\
\hline 7 & 887.5 & 1024 & 1450 & 1909 & 1579 & 984 & 724.8 & 515.9 & 345.3 & 208.7 & 50 \\
\hline 8 & 1390 & 1262 & 756.5 & 214.3 & 120.4 & 122.1 & 119.9 & 123.8 & 133.2 & 131.9 & 77.6 \\
\hline 9 & 336.2 & 402.5 & 570.8 & 675.2 & 703.6 & 682 & 586.1 & 492.8 & 381.1 & 304.4 & 201 \\
\hline 10 & 374.3 & 504.3 & 585.1 & 654.4 & 701.6 & 681.8 & 578.3 & 485.5 & 380.7 & 307.8 & 215.7 \\
\hline 11 & 329.6 & 281.3 & 338.8 & 363.2 & 186.7 & 150.2 & 130.6 & 125.1 & 120.9 & 120 & 111.4 \\
\hline 12 & 294.9 & 172.2 & 85 & 25.6 & 19.9 & 19.25 & 19.1 & 19 & 19.15 & 18.7 & 21.2 \\
\hline 13 & 1583 & 930.9 & 460.5 & 87.22 & 28.94 & 8.95 & 7.4 & 7.6 & 7.15 & 6.7 & 6.6 \\
\hline 14 & 479.8 & 525.6 & 650.2 & 903.5 & 755.8 & 675.8 & 558.6 & 466.5 & 375.6 & 305.5 & 220 \\
\hline 15 & 156.8 & 126.2 & 55.4 & 21.7 & 14.2 & 13.9 & 14.1 & 14.13 & 14 & 12.95 & 13.4 \\
\hline 16 & 292.2 & 80.52 & 22.8 & 18.12 & 21.7 & 22.2 & 19.3 & 18.65 & 21.2 & 21.85 & 21.1 \\
\hline 17 & 137.9 & 23.5 & 22.7 & 20.1 & 24.1 & 20.9 & 18.2 & 19.7 & 21.9 & 20.3 & 21.1 \\
\hline 18 & 407.3 & 103.8 & 25 & 23.3 & 18.2 & 17.4 & 17.43 & 18.9 & 20.8 & 19.7 & 22.6 \\
\hline 19 & 72.96 & 38.7 & 27.8 & 26.78 & 26.8 & 25.2 & 21.4 & 21.7 & 21.85 & 20.75 & 21.2 \\
\hline 20 & 965.2 & 974.2 & 1174 & 1454 & 1157 & 982.9 & 882.4 & 835.9 & 824.4 & 805.9 & 800.9 \\
\hline 21 & 510.8 & 562.9 & 645.2 & 800 & 860.2 & 730.1 & 528.2 & 407.5 & 285.1 & 224.7 & 204.5 \\
\hline 22 & 629.6 & 584.6 & 470 & 453.2 & 348.1 & 187.7 & 135.9 & 114.7 & 102.3 & 84.9 & 63.5 \\
\hline 23 & 621.2 & 712.9 & 800 & 900.1 & 982.5 & 900.7 & 656.8 & 452.4 & 262.5 & 157.5 & 126 \\
\hline 24 & 113.2 & 90.6 & 96.1 & 91.48 & 97.3 & 101.4 & 101 & 95.6 & 89.15 & 76.9 & 70.2 \\
\hline 25 & 1285 & 1594 & 1467 & 1534 & 1720 & 1802 & 1669 & 1433 & 392 & 219.5 & \\
\hline 26 & 333.6 & 316.5 & 390.7 & 328.7 & 382.5 & 432 & 534.4 & 603.9 & 591.9 & 489.6 & \\
\hline 27 & 836.4 & 1163 & 1600 & 1715 & 1690 & 1469 & 1206 & 1086 & 789.6 & & \\
\hline 28 & 826.2 & 959.2 & 950.4 & 1144 & 1369 & 1283 & 1023 & 788.7 & 509.9 & & \\
\hline 29 & 1129 & 1392 & 1718 & 2163 & 2180 & 1750 & 1396 & 1056 & 653.9 & 413.6 & \\
\hline 30 & 158.7 & 178.5 & 260.4 & 467.4 & 680.5 & 760.7 & 686.8 & 654.9 & 526.7 & 374.8 & \\
\hline
\end{tabular}

$(2 / 3)$ of half the current electrode separation $(A B / 2)$, the iso-resistivity of the sounding points across the study area were calculated. Contour maps of the iso-resistivity values at specific depth intervals of $A B / 2$ equal to $10 \mathrm{~m}$, $15 \mathrm{~m}, 24 \mathrm{~m}, 50 \mathrm{~m}, 75 \mathrm{~m}, 100 \mathrm{~m}, 150 \mathrm{~m}, 200 \mathrm{~m}, 250 \mathrm{~m}$, $300 \mathrm{~m}$, and $500 \mathrm{~m}$ (Table 2) were generated as shown in Figure 11. The contour maps revealed a continuos varia- tion of resistivity values with depth, suggesting a high resistive overburden. However, an iso-resistivity map is a qualitative interpretative tool which shows possible variations in resistivity at the given electrode spacing and does not give the true resistivities of a definite geo-electric layer [24].

The iso-resistivity map for $\mathrm{AB} / 2=10 \mathrm{~m}$ revealed that 
part of the study area corresponding to the Ameki Formations of Ibeku are underlain by relatively low resistive materials. The colour codes in Figure 11 reveal that colours between 50 and 150 corresponded to conductive horizons while highly resistive areas of about $1550 \Omega \mathrm{m}$ are indicative of sandy units. A similar trend is maintained in all the iso-resistivity plots from $\mathrm{AB} / 2$ equal to $10 \mathrm{~m}, 15$ m, 24 m, 50 m, 75 m, 100 m, 150 m, 200 m, 250 m, 300 $\mathrm{m}$, and $500 \mathrm{~m}$ revealing very low resistivity values in the southwestern part around Ibeku to a depth of over 350 metres. The Iso-resistivity maps therefore indicated that the northwestern section of the study area may be unproductive of groundwater to depths less than $350 \mathrm{~m}$.

\section{Discussion}

High $\mathrm{S}$ and low $\mathrm{T}_{\mathrm{r}}$ values were obtained generally for the aquiferous zones in the Ameki Formation while relatively low $S$ but high $T_{r}$ values were obtained for the aq- uiferous zones in the Benin Formation. The high S values obtained in the Ameki Formation can be attributed to higher salinity of the groundwater or high clay content or both. Sufficiently high $\mathrm{T}_{\mathrm{r}}$ coupled with good aquifer thickness is necessary for groundwater exploitation. Consequently the most prospective areas for drilling of productive boreholes in the study area have been delineated in the vicinities of Umuahia Township, Olokoro, Umudike, among others.

The depth to the water table estimated from this study revealed an increasing trend as we move from Ibeku area to Umuahia Township, Olokoro and Umudike areas. Deeper depths to the water table coupled with very low transmissivity properties of the aquifer materials make the environment of the Ameki Formation low in groundwater potentials. It is therefore observed that the northeastern lowlands have low groundwater potentials while the western area has high groundwater potentials. Similarly, a good correlation is found to exist between the

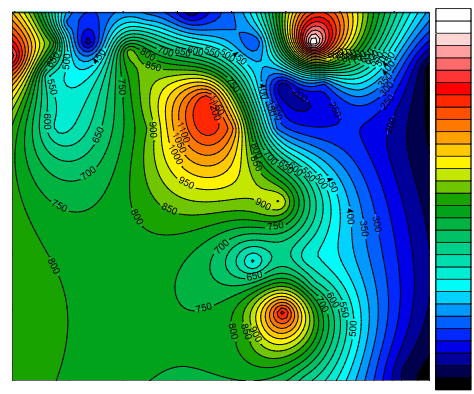

(a)

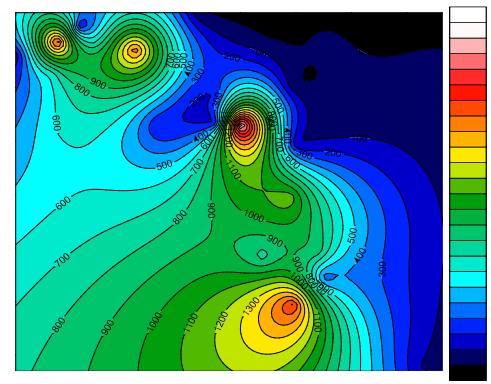

(e)

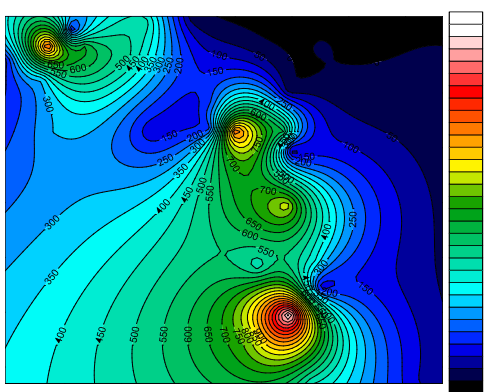

(h)

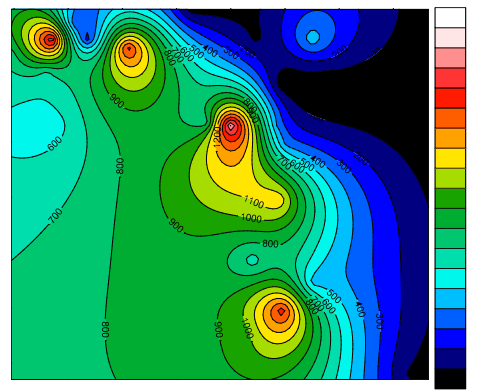

(b)

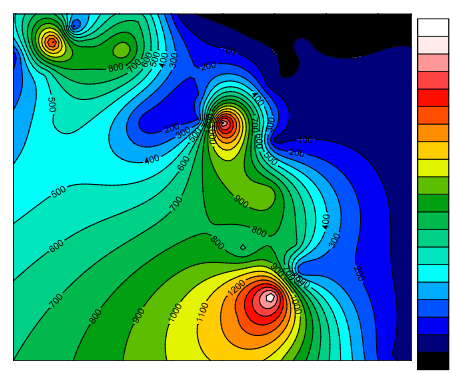

(f)

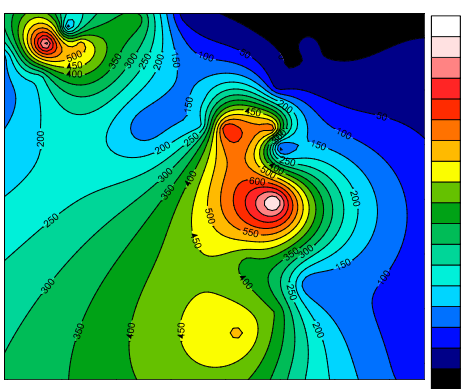

(i)

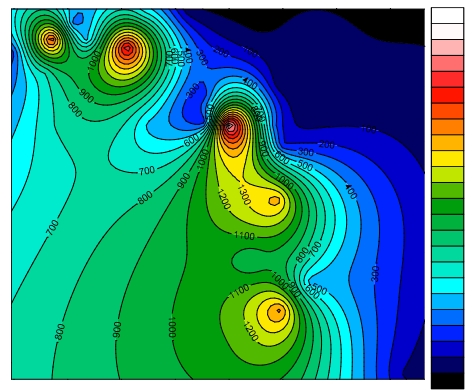

(c)

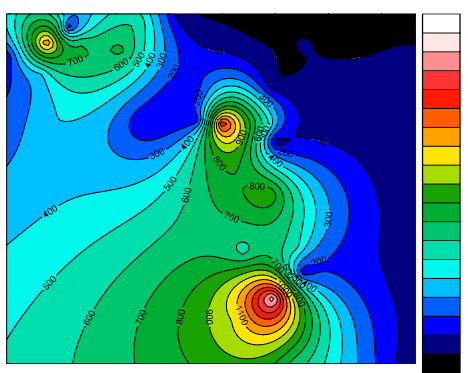

(g)

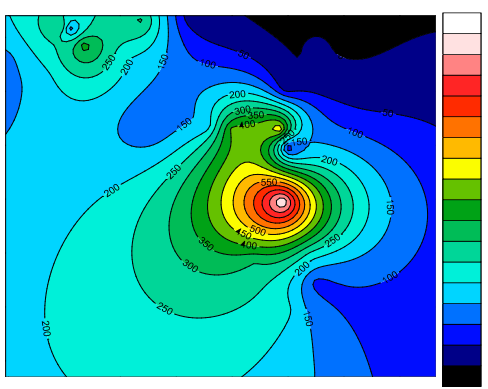

(j)

Figure 11. Iso-resistivity contour maps of the study area: (a) $A B / 2=10$, (b) $A B / 2=24$; (c) $A B / 2=50$; (d) $A B / 2=7.5$; (e) $A B / 2$ = 100, (f) $\mathrm{AB} / 2$ = 150; (g) $\mathrm{AB} / 2=200 ;$ (h) $\mathrm{AB} / 2=250$ and (i) $\mathrm{AB} / 2=350 \mathrm{~m}$. 
results generated from surface geophysical data and some borehole data. The zone with the highest transverse resistance $\left(T_{r}\right)$ values is expected to give the highest borehole yield. Consequently, favourable areas for future groundwater development have been suggested on the above bases.

In addition, the Iso-resistivity maps for $\mathrm{AB} / 2$ at $75 \mathrm{~m}$, $100 \mathrm{~m}$ and $150 \mathrm{~m}$ revealed that two distinct zones can be identified within the study area on the basis of resistivity values. They include the south-eastern part which covers about $3 / 4$ of the study area which is underlain by relatively high resistive materials with resistivities ranging from $202 \Omega \mathrm{m}$ near VES 4 to $2180 \Omega \mathrm{m}$ near VES 30 with a mean of $762.59 \Omega \mathrm{m}$. The north-western part on the other hand is underlain by relatively conductive materials at this interval. The resistivity values in this area range from $14.2 \Omega \mathrm{m}$ near VES 15 to $28.94 \Omega \mathrm{m}$ near 13 VES with a mean of $21.98 \Omega \mathrm{m}$. This variation between the two areas may possibly be traced to the variation in geology, topography or water quality and/or degree of saturation. A groundwater divide was established by previous scholars based on geo-sounding results revealing a prolific aquiferous zone within the Benin Formation and dearth of groundwater within the Ameki Formation [24, 25]. Igbokwe et al. [25], maintained that the two principal geological formations have comparative groundwater regime. The Ameki Formation has little groundwater potentials when compared to the Benin Formation.

Based on the generated geo-electric sections, which correlated well with strata-logs from boreholes in the study area, five to six (5 to 6) prominent geo-electric layers were identified in the south-eastern part of the study area whereas the north-western section of the study area has 2 to 3 geo-electric layers with overlying shale beds. Results revealed that aquifer apparent resistivity in the study area ranges from about 50 to $850 \Omega \mathrm{m}$ with the aquifer depth varying between 0.53 - $82.67 \mathrm{~m}$ with very low depths in the northwestern part around Ajata Ibeku. Similarly, aquifer thickness in the study area ranges from 0.8 - $110 \mathrm{~m}$ with very low thicknesses around Ajata Ibe$\mathrm{ku}$. Transverse resistance in the study area ranges from $2000-3400 \Omega \mathrm{m}^{2}$ with low values in the northwestern part with the iso-resistivity maps revealing that the northwestern section of the study area may not be productive of groundwater to a probable depth of $350 \mathrm{~m}$. This is because the transverse unit resistance $\left(T_{r}\right)$ which is a product of aquifer thickness (h) and resistivity $(\Omega$ ), is closely related to transmissivity ( $\mathrm{T}$ ) which is a product of aquifer thickness and hydraulic conductivity (K). Thus the southeastern and central parts of the study area where the total transverse unit resistance values are high, are expected to correlate with areas having high hydraulic transmissivity (T) and storage coefficient whereas the northwestern parts of the study area with low values of total transverse unit resistance $\left(T_{r}\right)$ are expected to have low transmissivity $(T)$ and permeability values. These results are in agreement with previous studies carried out earlier in the study area $[1,24,25,30]$.

\section{Summary and Conclusion}

The electrical resistivity sounding method is widely used for groundwater exploration and has found serious applications worldwide. Two important limitations are however inherent in this method. These are the problems of equivalence and suppression. However, computer oriented direct interpretation methods are capable of resolving the thickness and resistivities of various subsurface layers from the surface resistivity measurements. These results are free from human bias, which is always present in the conventional curve matching techniques.

The present study has helped to map out zones for the drilling of productive boreholes in the study area. The iso-resistivity plots of the study area have proven why most boreholes drilled within the Ameki Formation, especially within Ibeku area, east of Umuahia have serious underground water problems. Boreholes drilled in these areas that are shallower than $300 \mathrm{~m}$ may be unproductive. It is therefore hoped that results of this study will be invaluable to planning of water supply schemes within the area.

\section{REFERENCES}

[1] K. O. Uma, “An Appraisal of the Groundwater Resources of the Imo River Basin, South eastern Nigerian,” Journal of Mining and Geology, Vol. 25, No. 1\&2, 1989, pp. 305315. http://dx.doi.org/10.1007/s12594-012-0126-8

[2] A. C. Ekwe and A. I. Opara, “Aquifer Transmissivity from Surface Geoelectrical Data: A Case Study of Owerri and Environs, Southeastern Nigeria,” Journal of the Geological Society of India, Vol. 80, No. 1, 2012, pp. 355378.

[3] A. I. Opara, N. N. Onu and D. U. Okereafor, "Geophysical Sounding for the Determination of Aquifer Hydraulic Characteristics from Dar-Zurrock Parameters: Case study of Ngor Okpala, Imo River Basin, Southeastern Nigeria,” Pacific Journal of Science and Technology, Vol. 13, No. 1, 2012, pp. 590-603.

[4] H. T. Nejad, M. Mumipour, R. Kaboli and H. Najib, "Vertical Electrical Sounding (VES) Resistivity Survey Technique to Explore Groundwater in the Arid Region, Southeastern Iran,” Journal of Applied Sciences, Vol. 11, 2011, pp. 3765-3774.

[5] A. C. Ekwe, I. N. Nnodu, K. I. Ugwumbah and O. S. Onwuka, "Estimation of Aquifer Hydraulic Characteristics of Low Permeability Formation from Geosounding Data: A Case Study of Oduma Town, Enugu State,” Online Journal of Earth Sciences, Vol. 4, 2010, pp. 19-26. http://dx.doi.org/10.3923/ojesci.2010.19.26

[6] R. K. Majumdar and D. Das, "Hydrological Characterization and Estimation of Aquifer Properties from Electrical 
Sounding Data in Sagar Island Region, South 24 Parganas, West Bengal, India," Asian Journal of Earth Sciences, Vol. 4, 2011, pp. 60-74. http://dx.doi.org/10.3923/ajes.2011.60.74

[7] E. O. Joshua, O. O. Odeyemi and O. O. Fawehinmi, “Geoelectric Investigation of the Groundwater Potential of Moniya Area, Ibadan,” International Research Journal of Geology and Mining, Vol. 3, 2011, pp. 54-62.

[8] J. Danielson, T. Dahlin, R.Owen, P. Mangeya and E. Auken, "Geophysical and Hydrogeologic Investigation of Groundwater in the Karoo Stratigraphic Sequence of Sawmills in Northern Mata beleland, Zimbabwe: A Case History,” Hydeogeological Journal, Vol. 15, 2007, pp. 945-960. http://dx.doi.org/10.1007/s10040-007-0191-z

[9] A. S. Akinwumiju and O. O. I. Orimoogunje, "Determining the Occurrence of Freshwater in the Aquifers of the Deltaic Formation, Niger Delta Nigeria,” Journal of Environmental \& Analytical Toxicology, Vol. 3, No. 1, 2013, pp. 1-6.

[10] J. C. Egbai, "Vertical Electrical Sounding for the Determination of Aquifer Transmissivity," Australian Journal of Basic and Applied Sciences, Vol. 5, 2011, pp. 12091214.

[11] S. N. Rai, S. Thiagarajan, Y. Ratna, V. kumari, R. Anand and A. Manglik, "Delineation of Aquifers in Basaltic Hard Rock Terrain Using Vertical Electrical Soundings Data," Journal of Earth System Science, Vol. 122, No. 1, 2013, pp. 29-41.

[12] S. A. Van-dycke and M. Aboagye, "Geoelectrical Investigation of Groundwater Resources and Aquifer Characteristics in Some Small Communities in the Gushiegu and Karaga Districts of Northern Ghana,” International Journal of Scientific \& Technology Research, Vol. 2, No. 3, 2013, pp. 25-35.

[13] G. Onwuchuriba, "Hydrogeochemical Analysis of Groundwater Samples in Umuahia and Environs,” Unpublished Bachelor of Science Thesis, Federal University of Technology, Owerri, 2002, $114 \mathrm{p}$.

[14] S. Onyekuru, "Depositional Patterns of Upper Cretaceous Sediments in the Southeastern Part of Anambra Basin, Southeastern Nigeria,” Unpublished Ph.D. Thesis, Federal University of Technology, Owerri, 2010, 280 p.

[15] R. A. Reyment, “Aspects of the Geology of Nigeria,” Ibadan University Press, 1965, pp. 56-63.

[16] A. J. Whiteman, "Nigeria: Its Petroleum Geology, Resources and Potential," Graham and Trottan, London, 1982, $394 \mathrm{p}$.

[17] I. Arua, "Paleoenvironment of Eocene Deposits in the Afikpo Syncline, Southern Nigeria," Journal of African Earth Sciences, Vol. 5 No. 33, 1986, pp. 279-284. http://dx.doi.org/10.1016/0899-5362(86)90017-5
[18] K. O. Uma and B. C. E. Egboka, "Groundwater Potentials of Owerri and Its Environs," Geology and Mineral Resources of Nigeria, Vol. 22, 1985, pp. 57-64.

[19] A. C. Onyeagocha, "Petrography and Depositional Environment of the Benin Formation Nigeria," Journal of Mining and Geology, Vol. 17, No. 2, 1980, pp. 147-151.

[20] L. O. Asseez, "Review of the Stratigraphy, Sedimentation and Structure of the Niger Delta. In: C. A. Kogbe, Ed., Geology of Nigeria, Eliza Beth Publishing Co., Lagos, 1976, $120 \mathrm{p}$.

[21] A. A. Avbovbo, "Tertiary Lithostratigraphy of Niger Delta," Bulletin of American Association of Petroleum Geologists, Vol. 6, 1978, pp. 295-306.

[22] P. D. C. Mbonu, J. O. Ebeniro, C. O. Ofoegbu and A. S. Ekine, "Geoelectric Sounding for the Determination of Aquifer Characteristics in Parts of the Umuahia Area of Nigeria,” Geophysics, Vol. 56, No. 2, 1991, pp. 284-291. http://dx.doi.org/10.1190/1.1443042

[23] M. U. Igbokwe, E. E. Okwueze and C. S. Okereke, "Delineation of Aquifer Zones from Geoelectric Soundings in Kwa Ibo River Water shed, Southeastern Nigeria,” Journal of Engineering and Applied Sciences, Vol. 1, No. 4, 2006, pp. 410-421.

[24] P. Vingoe, "Electrical Resistivity Surveying," ABEM Geophysical Memorandum, Vol. 5, No. 72, 1972, pp. 1-3.

[25] A. A. R. Zohdy, “Application of Surface Geophysics (Electrical Methods to Groundwater Investtigations),” Techniques for Water Resources Investigations in the United States, Section D, Book 2, 1976, pp. 5-55.

[26] O. Koefoed, "Geosounding Principles 1. Resistivity Sounding Measurements,” Elsevier, Amsterdam, 1977, p. 277.

[27] J. E. Osemeikhian and M. B. Asokhia, "Applied Geophysics for Engineers and Geologists,” Mc-Graw Hill, 1982, p. 155.

[28] A. C. Ekwe, N. N. Onu and K. M. Onuoha, "Estimation of Aquifer Hydraulic Characteristics of Aquifer Hydraulic Characteristics from Electrical Sounding Data: A Case of Middle Imo River Basin Aquifers, South Eastern Nigeria,” Journal of Spatial Hydrology, Vol. 6, 2006, pp. 121132.

[29] S. D. Schwarz, “Application of Geophysical Methods to Groundwater Exploration in the Tolt River Basin, Washington State," Geotechnical and Environmental and Engineering Geophysical Society European Section, E.E.G.S., 1988, pp. 9-12.

[30] R. A. Van Overmeeren, “Aquifer Boundaries Explored by Geoelectrical Measurements in the Coastal Plain of Yemen: A Case of Equivalence,” Geophysics, Vol. 54, No. 1, 1989, pp. 38-48. http://dx.doi.org/10.1190/1.1442575 